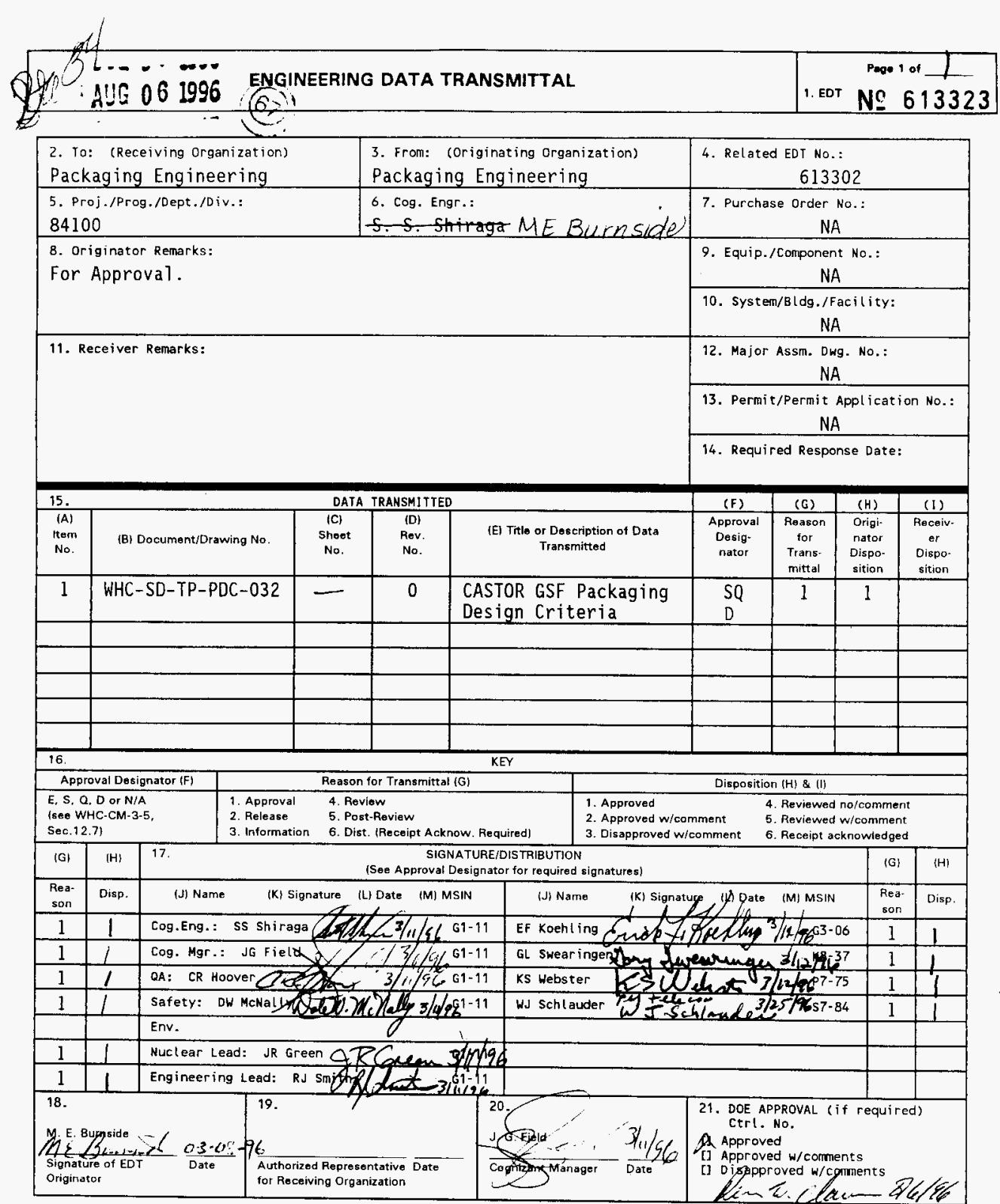

BD-7400-972-2(04/94) GEF097 


\section{CASTOR GSF PACKAGING DESIGN CRITERIA}

S.-S.-Sirage M.E. Burnside

Westinghouse Hanford Company, Richland, WA 99352

U.S. Department of Energy Contract DE-AC06-87RL10930

EDT/ECN: EDT 613323

Org Code: 84100

B\&R Code: YNO100000

UC: 512 .

Charge Code: BEl221

Total Pages: 453

Key Words: CASTOR GSF, Packaging Design Criteria, 324 Building, 300 Area, Pacific Northwest National Laboratories

Abstract: Encapsulated vitrified materials (Isotopic Heat Sources) are currently stored in the Pacific Northwest National Laboratories (PNNL) 324 Building located in the 300 Area. As part of the 324 Building transition program, the vitrified material, encapsulated in stainless steel canisters, must be removed. These canisters were originally intended to be used by the German government, but are no longer desired. As part of an agreement with the German government, the Germans are providing the U.S. Department of Energy (DOE) with six (6) CASTOR GSF and four (4) GNS-12 casks. The canisters will be transported onsite in CASTOR GSF and GNS-12 casks for interim storage until final disposition of the material is determined.

TRADEMARK DISCLAIMER. Reference herein to any specific comercial product, process, or service by trade name, trademark, manufacturer, or otherwise, does not necessarily constitute or imply its endorsement, recommendation, or favoring by the United States Goverment or any agency thereof or its contractors or subcontractors.

Printed in the United States of America. To obtain copies of this document, contact: WHC/BCS Document Control Services, P.0. Box 1970, Mailstop 16-08, Richland WA 99352, Phone (509) 372-2420; Fax (509) 376-4989.
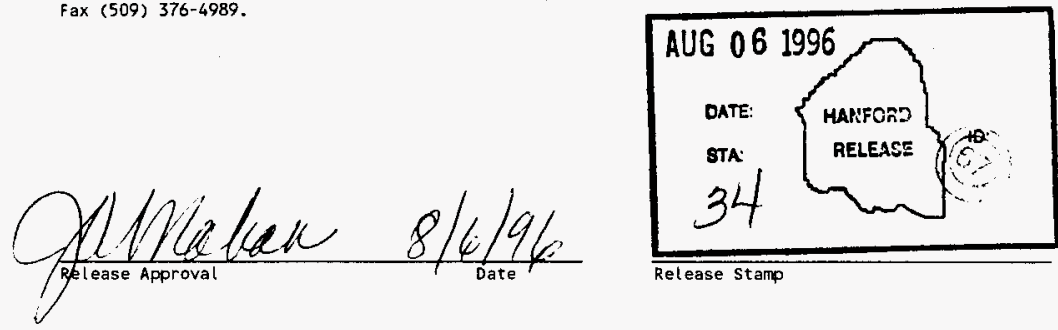

Release Stamp

\section{Approved for Public Release}




\section{CONTENTS}

1.0 INTRODUCTION . . . . . . . . . . . . . . . . . . . 1

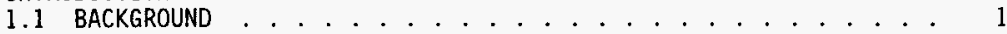

1.2 PURPOSE AND SCOPE . . . . . . . . . . . . . . 1

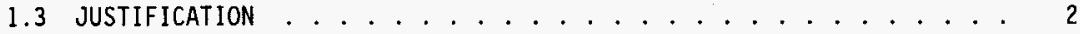

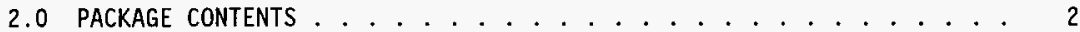

2.1 PAYLOAD DESCRIPTION ................. 2

2.2 RADIOACTIVE MATERIALS .............. 2

2.2.1 Source Term . . . . . . . . . 3

2.3 CHEMICAL CONSTITUENT SOURCE TERM . . . . . . . . . . . . 5

2.4 GAS GENERATION .................... . . 6

2.5 TRANSPORTATION CLASSIFICATION . . . . . . . . . . . . 6

2.6 FISSILE CLASSIFICATION . . . . . . . . . . . . . . . 6

2.7 CONTENT RESTRICTIONS ................. . . 6

3.0 FACILITY OPERATIONS . . . . . . . . . . . . . 7

3.1 ORIGINATING SITE -324 BUILDING . . . . . . . . . . . . . . 7

3.2 DESTINATION SITE . . . . . . . . . . . . . 7

4.0 PACKAGING/TRANSPORT SYSTEM DESIGN . . . . . . . . . . 7

4.1 GENERAL . . . . . . . . . . . . . . . . . . . . . 7

4.2 PACKAGING DESIGN CRITERIA . . . . . . . . . . . . 7

4.2.1 Packaging Specification and Materials . . . . . . . 7

4.2.2 Packaging Dimensions . . . . . . . . . . . . . . . 99 9

4.2.3 Maximum Gross Weight . . . . . . . . . . . . . . . 9

4.2.4 Tiedown Attachments . . . . . . . . . . . . . . . . 9 9

4.2 .5 Lifting Attachments . . . . . . . . . . . . 10

4.2 .6 Venting ................ . . . 10

4.2.7 Closure Design and Containment . . . . . . . . 10

4.2 .8 Shielding . . . . . . . . . . . . . . . . 10

4.2 .9 Service Life. . . . . . . . . . . . . . . . . . . 11

4.2.10 Chemical and Galvanic Reactions .......... 11

4.2.11 Heat Dissipation ............... . . 11

4.2.12 Surface Contamination ............. . 11

4.3 TRANSPORT SYSTEM . . . . . . . . . . . . . . . . 11

4.3.1 Transport vehicle ............... . . 11

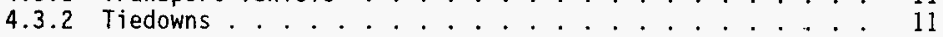

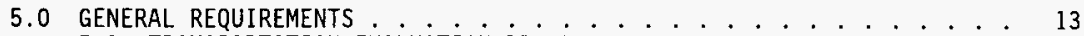

5.1 TRANSPORTATION EVALUATION REQUIREMENTS ........... 13

5.1.1 Norma 1 Transfer Conditions ............. 13

5.1.2 Accident Events .................. 13

5.1.3 Thermal . . . . . . . . . . . . . . . 14

5.2 AS LOW AS REASONABLY ACHIEVABLE . . . . . . . . . . . . . 14

5.3 QUALITY ASSURANCE . . . . . . . . . . . . . . . . 14

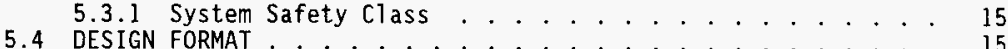


WHC-SD-TP-PDC-032 Rev, 0

CONTENTS (cont)

5.5 ENVIRONMENTAL COMPLIANCE . . . . . . . . . . . . . 15

5.6 MAINTENANCE .......................... . . . . . . 15

5.7 REUSE . . . . . . . . . . . . . . . . . 15

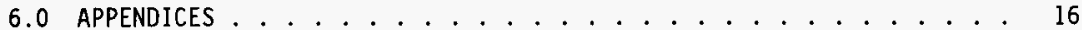

6.1 REFERENCES . . . . . . . . . . . . . . 16

6.2 SOURCE TERM INFORMATION FROM THE CASTOR GSF SAR . . . . . . . . 18

6.3 SAFETY CLASS EVALUATION . . . . . . . . . . . . . 28

\section{LIST OF FIGURES}

1 Heat Source (Canister) Payload Configuration. . . . . . . . . . . . 3

2 Canister Filling Process. . . . . . . . . . . . . . . . . 3

3 Canister Campaign Graphs. . . . . . . . . . . . . . . . . . . . 4

4 CASTOR GSF Configuration. . . . . . . . . . . . . . . . 8

\section{LIST OF TABLES}

1 CASTOR GSF Source Term . . . . . . . . . . . . . . . . . 5

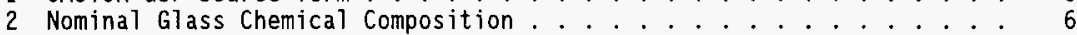

3 CASTOR GSF Cask Dimensions . . . . . . . . . . . . . . . . . . 9

4 Decontamination Limits...................... 11 
WHC-SD-TP-PDC-032 Rev. 0

\section{LIST OF TERMS}

$\begin{array}{ll}\text { ALARA } & \text { As Low As Reasonably Achievable } \\ \text { Bq } & \text { Bequerels } \\ \text { CFR } & \text { Code of Federal Regulations } \\ \text { Ci } & \text { Curies } \\ \text { CWC } & \text { Central Waste Complex } \\ \text { DOE } & \text { U.S. Department of Energy } \\ \text { DOT } & \text { U.S. Department of Transportation } \\ \text { HRCQ } & \text { Highway Route Controlled Quantity } \\ \text { IAEA } & \text { International Atomic Energy Agency } \\ \text { mm } & \text { millimeters } \\ \text { NRC } & \text { U.S. Nuclear Regulatory Commission } \\ \text { OSHA } & \text { Occupational Safety and Health Administration } \\ \text { PDC } & \text { Packaging Design Criteria } \\ \text { Pacific } & \text { Pacific Northwest National Laboratories } \\ \text { Northwest } & \\ \text { QA } & \text { Quality Assurance } \\ \text { R/h } & \text { Roentgen per hour } \\ \text { RL } & \text { U.S. Department of Energy, Richland Operations office } \\ \text { RQ } & \text { Reportable Quantity } \\ \text { SAR } & \text { Safety Analysis Report } \\ \text { SARP } & \text { Safety Analysis Report for Packaging } \\ \text { SV/h } & \text { Sieverts per hour } \\ \text { WHC } & \text { Westinghouse Hanford Company }\end{array}$


WHC-SD-TP-PDC-032 Rev. 0

\section{CASTOR GSF PACKAGING DESIGN CRITERIA}

\subsection{INTRODUCTION}

\subsection{BACKGROUND}

Encapsulated vitrified materials (Isotopic Heat Sources) are currentiy stored in the Pacific Northwest National Laboratories (Pacific Northwest) 324 Building located in the 300 Area. As part of the 324 Building transition program, the vitrified material, encapsulated in stainless steel canisters, must be removed. These canisters were originally intended to be used by the German government, but are no longer desired. As part of an agreement with the German government, the Germans are providing the U.S. Department of Energy (DOE) with six (6) CASTOR GSF and four (4) GNS-12 casks. The canisters will be transported onsite in CASTOR GSF and GNS-12 casks for interim storage until final disposition of the material is determined. This Packaging Design Criteria (PDC) covers the CASTOR GSF; the GNS-12 is addressed in a separate PDC. The CASTOR GSF cask was designed and fabricated by Gesellschaft für Nuklear-Service mbH, Essen, Germany to be a certified Type $B(U)$ Packaging, which complies with the requirements of the International Atomic Energy Agency (IAEA) for transport of up to five (5) sealed canisters of vitrified radioactive materials. However, this cask was never actually certified for use.

\subsection{PURPOSE AND SCOPE}

The purpose of this PDC is to provide criteria for the onsite Safety Analysis Report for Packaging (SARP). The SARP will provide the evaluation to support packaging requirements for the safe and economic transport and storage of the 324 Building vitrified encapsulated material in the CASTOR GSF cask. In this application, the approved POC provides a formal set of standards for the payload requirements, and guidance for the evaluation and tiedown design.

The SARP will be approved by Pacific Northwest, ICF Kaiser, and the Westinghouse Hanford Company (WHC), including Quality Assurance (QA) and Safety, to authorize onsite interarea transfer. Due to the large quantities of radioactive materials (>3000 $\left.\mathrm{A}_{2}{ }^{\prime} \mathrm{s}\right)$, the shipment will be classified as Highway Route Controlled Quantity (HRCQ). Therefore, the SARP will also require the approval of the U.S. Department of Energy, Richland Operations office (RL).

The SARP will evaluate how the vitrified encapsulated material will perform during normal transport conditions and after credible accident events. The packaging system and administrative controls set forth in the SARP will ensure the system meets the onsite transportation requirements of WHC-CM-2-14, Hazardous Material Packaging and Shipping. 


$$
\text { WHC-SD-TP-PDC-032 Rev. } 0
$$

\subsection{JUSTIFICATION}

Presently, there are thirty-four (34) steel canisters being stored in the 324 Building. This material must be removed to allow for the 324 Building to be decommissioned. The cask that will be used for onsite shipment and storage must:

1. Provide adequate shielding for operational personnel.

2. Maintain containment of the encapsulated vitrified material in its original configuration during normal and accident transport conditions.

3. Effectively dissipate thermal heat loads.

4. Maintain the material in a nonreactive environment during storage.

5. Be compatible with the 324 Building facility and operation requirements.

6. Provide ease of operation for loading, unloading, transporting, maintaining, and storing.

All of these requirements are met by the CASTOR GSF cask, which was specifically developed for this payload.

\subsection{PACKAGE CONTENTS}

\subsection{PAYLOAD DESCRIPTION}

The payload (Figure 1) for the CASTOR GSF packaging system will consist of borosilicate glass encapsulated in steel canisters (PNL-6790/UC-510). The borosilicate glass matrix constituents were immobilized to yield a product with a predetermined thermal decay heat and surface radiological dose rate. The canisters' radiochemical characteristics for thermal heat load, range between 1330 and $2285 \mathrm{~W}$ each. Radiological gamma exposure rates, on contact, are between $112,000 \mathrm{R} / \mathrm{h}(1,120 \mathrm{~Sv} / \mathrm{h})$ to $310,000 \mathrm{R} / \mathrm{h}(3,100 \mathrm{~Sv} / \mathrm{h})$. For purposes of this PDC, $100 \mathrm{R} / \mathrm{h}$ is conservatively assumed to equal $1 \mathrm{~Sv} / \mathrm{h}$. Each canister weighs approximately $250 \mathrm{~kg}(550 \mathrm{lb})$, with a density of $2.8 \mathrm{~kg} / 0.1 \mathrm{~m}^{3}$.

\subsection{RADIOACTIVE MATERIALS}

The vitrified encapsulated material to be transported contains significant amounts of ${ }^{137} \mathrm{Cs}$ and ${ }^{90} \mathrm{Sr}$. Three specific production series (RLFCM-7, RLFCM-8, and RLFCM-9) were performed by Pacific Northwest during heat source (canister) development. Figure 2 shows the canister filling process. Figure 3 provides graphs depicting the specific oxide in glass weight percent of all three canister production series. 
Figure 1. Heat Source (Canister) Payload Configuration.

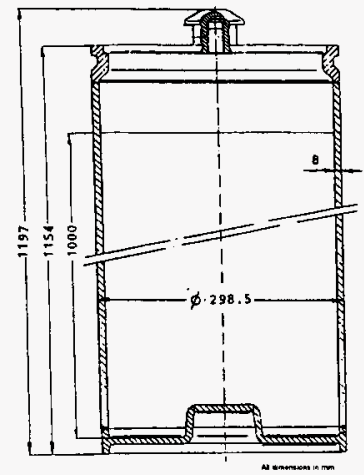

Figure 2. Canister Filling Process.

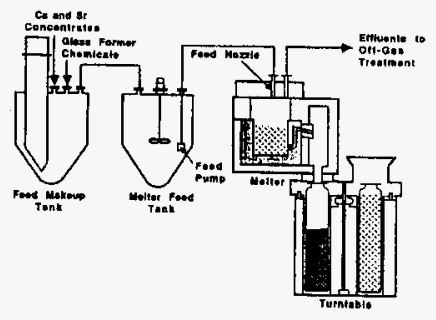

\subsubsection{Source Term}

The worst case cask canister inventory and source term composition were taken from the Safety Analysis Report (SAR) for the CASTOR GSF cask (GNS 1990). Section 6.2 contains source term information taken from the CASTOR GSF SAR. The CASTOR GSF cask will contain a maximum of five (5) canisters, and each canister is assumed to contain the worst case canister inventory identified in the CASTOR GSF SAR. Section 6.2 contains a spreadsheet which was used to convert the source term information from the CASTOR GSF SAR to activity values in curies (Ci). Note that the specific activities used in the spreadsheet were taken from the newly revised values 
WHC-SD-TP-PDC-032 Rev. 0

Figure 3. Canister Campaign Graphs.

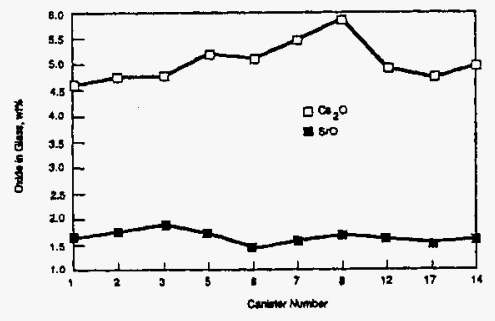

RLFOH-7 Ceslue and St rontive Concentrati ons

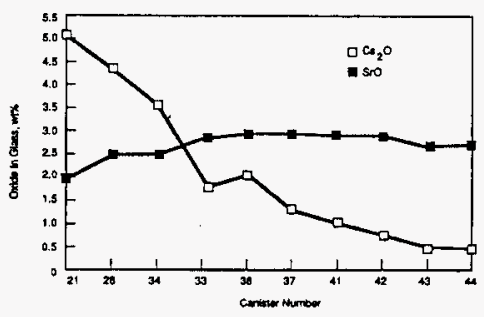

RLFDH-B Cesi un and Strontiun Concentrations

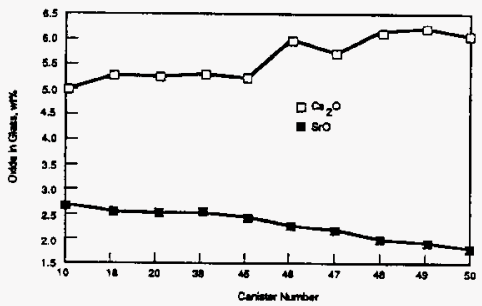

RLFoH-9 Cesila and Strontium Concentrations 
published in Federal Register 50319 (FR 50319). These values will take effect in April 1996. Since the shipments will be made after this date, it was decided to use the newer values at this time.

The activities from the spreadsheet contained in Section 6.2 were input into the ORIGEN2 computer code (Schmittroth 1993) and decayed for 20 years to identify decay products which would be present in the waste. The ORIGEN2 input file and pertinent output information are included in Section 6.2 . Table 1 lists the worst case canister activities from the CASTOR GSF SAR and the activities of the daughter products identified by ORIGEN2. It also lists the maximum cask activities assuming a loading of five (5) canisters per cask. If a daughter product identified by ORIGEN2 was not in equilibrium with the parent nuclide after 20 years, it was conservatively assumed to be in equilibrium with the parent nuclide. Note that numerous other decay products are calculated by ORIGEN2. However, these were not included because their activity is insignificant, and their effect on the radiological analysis is negligible.

Table 1. CASTOR GSF Source Term.

\begin{tabular}{|c|c|c|c|c|c|}
\hline Nuclide & $\begin{array}{c}\text { Single Canister } \\
\text { Activity, } \mathrm{Ci}\end{array}$ & $\begin{array}{l}\text { Maximum Cask } \\
\text { Activity, Ci* }\end{array}$ & Nuclide & $\begin{array}{l}\text { Single Canister } \\
\text { Activity, } \mathrm{Ci}\end{array}$ & $\begin{array}{c}\text { Maximum Cask } \\
\text { Activity, } \mathrm{Ci}^{\pi}\end{array}$ \\
\hline${ }^{\infty} \mathrm{Sr}$ & $2.1 E+05$ & $1.1 E+06$ & ${ }^{234} \mathrm{Th}$ & $3.4 \mathrm{E}-06$ & $1.7 \mathrm{E}-05$ \\
\hline$\infty Y$ & $2.1 E+05$ & $1.1 E+06$ & ${ }_{234 n \mathrm{~Pa}}$ & $3.4 \mathrm{E}-06$ & $1.7 \mathrm{E}-05$ \\
\hline${ }^{137} \mathrm{Cs}$ & $3.0 E+05$ & $1.5 E+06$ & ${ }^{234} \mathrm{U}$ & $5.3 \mathrm{E}-06$ & $2.7 \mathrm{E}-05$ \\
\hline${ }^{137+\mathrm{Ba}}$ & $2.8 E+0.5$ & $1.4 \mathrm{E}+06$ & ${ }^{235} \mathrm{U}$ & $1.9 E-07$ & $9.5 \mathrm{E}-07$ \\
\hline${ }^{2004} \mathrm{TI}$ & $1.2 \mathrm{E}-04$ & $6.0 \mathrm{E}-04$ & ${ }^{236} \mathrm{U}$ & $4.4 E-07$ & $2.2 \mathrm{E}-06$ \\
\hline${ }^{212} \mathrm{~Pb}$ & $3.3 \mathrm{E}-04$ & $1.7 \mathrm{E}-03$ & ${ }^{237} \mathrm{U}$ & 5.5 E-0.5 & $2.8 \mathrm{E}-04$ \\
\hline${ }^{212} \mathrm{Bi}$ & $3.3 \mathrm{E}-04$ & $1.7 \mathrm{E} .03$ & ${ }^{209} \mathrm{U}$ & $3.4 \mathrm{E}-06$ & $1.7 \mathrm{E}-05$ \\
\hline${ }^{212} \mathrm{Po}$ & 2.1 E- 04 & $1.1 \mathrm{E}-03$ & ${ }^{259} \mathrm{~Np}$ & $2.0 \mathrm{E}-01$ & $1.0 E+00$ \\
\hline${ }^{215} \mathrm{Po}$ & 3.3 E.04 & $1.7 \mathrm{E}-03$ & ${ }^{238} \mathrm{Pu}$ & $1.7 \mathrm{E}-01$ & $8.5 \mathrm{E}-01$ \\
\hline${ }^{2 x 0} \mathrm{Rn}$ & $3.3 \mathrm{E}-04$ & $1.7 \mathrm{E}-03$ & ${ }^{236} \mathrm{Pu}$ & $1.7 \mathrm{E}-01$ & B.5E-01 \\
\hline${ }^{224} \mathrm{Ra}$ & 3.3 E-04 & $1,7 \mathrm{E}-03$ & ${ }^{240} \mathrm{Pu}$ & $5.6 \mathrm{E}-02$ & $2.8 \mathrm{E}-01$ \\
\hline${ }^{22 a} \mathrm{Ra}$ & $3.3 \mathrm{E}-04$ & $1.7 \mathrm{E}-03$ & ${ }^{241} \mathrm{Pu}$ & $2.3 E+00$ & $1.2 E+01$ \\
\hline${ }^{228} \mathrm{AC}$ & $3.3 \mathrm{E}-0.4$ & $1.7 \mathrm{E}-03$ & ${ }^{2+2} \mathrm{Pu}$ & 4.6 E-05 & $2.3 \mathrm{E}-0.4$ \\
\hline${ }^{229} \mathrm{Th}$ & $3.3 \mathrm{E}-04$ & $1.7 \mathrm{E}-03$ & ${ }^{241} \mathrm{Am}$ & $3.4 \mathrm{E}+01$ & $1.7 E+00$ \\
\hline${ }^{23 \prime} \mathrm{Th}$ & $1.9 \mathrm{E}-07$ & $9.5 E-07$ & ${ }^{243} \mathrm{Am}$ & $2.0 \mathrm{E}-01$ & $1.0 E+00$ \\
\hline${ }^{232} \mathrm{Th}$ & 3.3 E-04 & $1.7 \mathrm{E}-03$ & TOTALS & $1.0 E+06$ & $5.1 E+06$ \\
\hline
\end{tabular}

a. Assumes a maximum of five canisters will be loaded in the CASTOR GSF cask.

\subsection{CHEMICAL CONSTITUENT SOURCE TERM}

Table 2 gives the nominal glass compositions for all three canister production campaigns. 
WHC-SD-TP-PDC-032 Rev. 0

Table 2. Nominal Glass Chemical Composition.

\begin{tabular}{|c|c|c|c|c|c|c|c|}
\hline $\begin{array}{c}\text { oxido } \\
\text { Compound }\end{array}$ & $\begin{array}{l}\text { Average Glass } \\
\text { Composition } \\
\text { RLFCM+7, wt\% }\end{array}$ & $\begin{array}{l}\text { Average Glass } \\
\text { Composition } \\
\text { RLFCM-8, wt } \%\end{array}$ & $\begin{array}{c}\text { Average Glass } \\
\text { Composition } \\
\text { RLFCM-9, w\% }\end{array}$ & $\begin{array}{l}\text { Oxide } \\
\text { Compound }\end{array}$ & $\begin{array}{l}\text { Average Glass } \\
\text { Composition } \\
\text { RL.FCM-7, wt\% }\end{array}$ & $\begin{array}{l}\text { Average Glass } \\
\text { Composition } \\
\text { RLFCM-8, wt \% }\end{array}$ & $\begin{array}{l}\text { Average Glass } \\
\text { Composition } \\
\text { RLFCM-9, wt\% }\end{array}$ \\
\hline $\mathrm{Al}_{2} \mathrm{O}_{3}$ & 2.88 & 2.58 & 2.17 & $\mathrm{MoO}_{3}$ & 0.05 & 0.00 & 0.00 \\
\hline $\mathrm{B}_{2} \mathrm{O}_{3}$ & 13.68 & $\$ 4.65$ & 14.84 & $\mathrm{Na}_{2} \mathrm{O}$ & 16.50 & 13.22 & 11.58 \\
\hline $\mathrm{BaO}$ & 1.05 & 1.13 & 1.02 & $\mathrm{Nd}_{2} \mathrm{O}_{3}$ & 0.65 & 0.71 & 0.89 \\
\hline $\mathrm{CaO}$ & 1.52 & 1.25 & 0.79 & No & 0.39 & 0.25 & 0.44 \\
\hline $\mathrm{CeO}_{2}$ & 0.06 & 0.05 & 0.07 & $\mathrm{PbO}$ & 0.16 & 0.00 & 0.00 \\
\hline $\mathrm{Cr}_{2} \mathrm{O}_{3}$ & 0.58 & 0.38 & 0.45 & $\mathrm{RuO}_{2}$ & 0.02 & 0.00 & 0.00 \\
\hline $\mathrm{Cs}_{2} \mathrm{O}$ & 5.02 & 2.08 & 5.74 & $\mathrm{SiO}_{2}$ & 41.25 & 48.02 & 46.59 \\
\hline $\mathrm{Fe}_{2} \mathrm{O}_{3}$ & 11.18 & 10.10 & 9.93 & Sro & 1.65 & 2.67. & 2.34 \\
\hline $\mathrm{La}_{2} \mathrm{O}_{3}$ & 1.04 & 1.07 & 1.53 & $\mathrm{TiO}_{2}$ & 0.19 & 0.07 & 0.03 \\
\hline $\mathrm{Li}_{2} \mathrm{O}$ & 0.31 & 0.00 & 0.00 & $\mathrm{ZnO}$ & 0.08 & 0.01 & 0.00 \\
\hline $\mathrm{MgO}$ & 0.78 & 0.54 & 0.44 & $\mathrm{ZrO}_{2}$ & 0.15 & 0.04 & 0.05 \\
\hline $\mathrm{MnO}_{2}$ & 0.80 & 1.20 & 1.11 & TOTALS & 100.00 & 100.00 & 100,00 \\
\hline
\end{tabular}

\subsection{GAS GENERATION}

Based upon the glass form of the radioactive material and the containment provided by the canisters, there will be no gas generation.

\subsection{TRANSPORTATION CLASSIFICATION}

For transportation purposes, the vitrified encapsulated material of this packaging is considered Type B, Reportable Quantities (RQ), HRCQ, Yellow III, Radioactive Material in accordance with WHC-CM-2-14.

\subsection{FISSILE CLASSIFICATION}

There is less than $15 \mathrm{~g}$ of fissile material; therefore, the payload shall be classified as fissile excepted for transportation.

\subsection{CONTENT RESTRICTIONS}

A single CASTOR GSF cask may contain up to a maximum of five steel GNF/GSF canisters. Each canister can contain a maximum activity of $297.0 \mathrm{kCi}$ $\left(1.1 \times 10^{16} \mathrm{~Bq}\right){ }^{137} \mathrm{Cs}$ and $207.9 \mathrm{kCi}\left(7.7 \times 10^{15} \mathrm{~Bq}\right){ }^{90} \mathrm{Sr} /{ }^{90} \mathrm{Y}$, respectively. The maximum thermal wattage of each canister is $2285 \mathrm{~W}$. The maximum weight of the payload without the basket (five canisters loaded) is $1250 \mathrm{~kg}$ (2750 ib). 
WHC-SD-TP-PDC-032 Rev. 0

\subsection{FACILITY OPERATIONS}

\subsection{ORIGINATING SITE - 324 BUILDING}

The vitrified material will be loaded in the CASTOR GSF cask in the 324 Hot Cells. The casks will be loaded onto the transport vehicle with an appropriate engineered tiedown system. Hanford "Master Safety Rules" and applicable Occupational Safety and Health Administration (OSHA) standards will be followed during all loading operations.

\subsection{DESTINATION SITE}

The current storage site of the loaded CASTOR GSF Cask is unknown. A storage site will be agreed apon and discussed in the SARP. In addition, overpack requirements for transport and storage will be discussed and evaluated in the SARP. The cask(s) will be unloaded from the transport vehicle and placed in the appropriate storage area. Hanford "Master Safety Rules" and applicable OSHA standards will be followed during all unloading operations.

\subsection{PACKAGING/TRANSPORT SYSTEM DESIGN}

\subsection{GENERAL}

The CASTOR GSF cask consists of a ductile cast iron and lead composite structure. The cask body and primary closure lid and seals form the primary containment system ensuring the integrity of the package. A secondary closure lid and seals form a secondary containment boundary. A basket is inserted in the cavity of the cask in order to secure the contents. The cask is handled with two lifting rings diametrically installed on the head of the cask body. In order to reduce the shock loading during transport accidents, impact limiters are mounted over the ends of the cask.

An evaluation of the rigging requirements and the tiedown system will be provided in the SARP.

\subsection{PACKAGING DESIGN CRITERIA}

\subsubsection{Packaging Specification and Materials}

4.2.1.1 CASTOR GSF Cask. The CASTOR GSF cask (Figure 4) structural design covers all safety related parts of the packaging in compliance with the requirements for transport. This includes analys is of all considered loads, stresses, and safety factors which are essential to meet the transportation standards for a Type B packaging under normal operations and hypothetical accident conditions. The CASTOR GSF cask structural design is based on a $9 \mathrm{~m}$ $(30 \mathrm{ft})$ drop criteria. 
The CASTOR GSF cask incorporates four basic components which maintain the structural integrity and safe confinement of its payload.

The four basic components are:

1. Impact Limiter System. The impact limiters consist of a closed sheet-steel construction filled with several plies of wood. The impact limiters protect the cask during hypothetical accident conditions.

2. Cask Body and Primary Lid. The main body of the cask is cast iron as a hollow cylinder of GGG 40 . The disk-shaped cylindrical body of the primary $1 \mathrm{id}$ is made of GGG 40 . In the surface where the primary lid rests on the cask body, there are two grooves to accept seals. The inner grove is designed to accept a metal seal. The outer groove is designed to accept an elastomer (silicone) seal.

3. Secondary Lid and Seal System. The secondary lid is a disc-shaped cylindrical steel body. The bearing surface of the lid has two grooves to accept one inner metal seal and one outer elastomer seal.

Figure 4. CASTOR GSF Configuration.

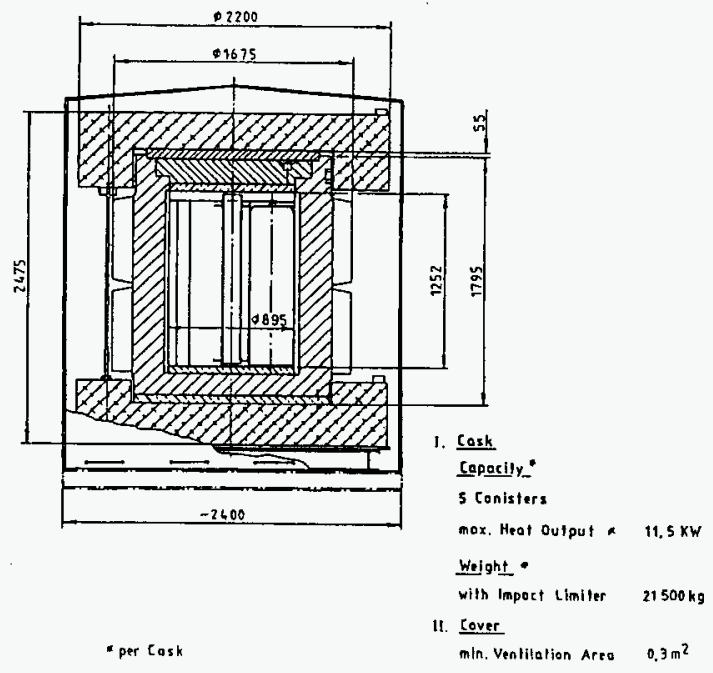


4. Basket. The basket is a tubular structure with five positions in on a circle to keep the payload in position (canisters). Each position is formed by a continuous steel tube.

\subsubsection{Packaging Dimensions}

Table 3 provides the nominal dimensions of the CASTOR GSF cask.

\subsubsection{Maximum Gross Weight}

The maximum loaded weight of the CASTOR GSF cask with impact limiters is $22,930 \mathrm{~kg}(50,550 \mathrm{lb})$. The weight of five canisters is $1250 \mathrm{~kg}(2750 \mathrm{~Tb})$.

\subsubsection{Tiedown Attachments}

During shipment, the cask is attached onto a shipping pallet or the base plate of the shipping container (intermodal frame or container) by means of the bottom impact limiter. This attachment method used for securement of the CASTOR GSF cask, is evaluated for safe and compliant onsite transportation in the Structural Evaluation section (Part B) of the SARP.

Table 3. CASTOR GSF Cask Dimensions.

\begin{tabular}{|l|c|c|}
\hline \multirow{2}{*}{ Description } & \multicolumn{2}{|c|}{ Dimension } \\
\cline { 2 - 3 } & in. & $\mathrm{cm}$ \\
\hline \hline Outside diameter with impact limiters & 86.6 & 220.0 \\
\hline Overall height with impact limiters & 97.4 & 247.5 \\
\hline Outside diameter without impact limiters & 65.9 & 167.5 \\
\hline Overall height without impact limiters & 70.1 & 179.5 \\
\hline Inner cavity height & 49.2 & 125.0 \\
\hline Inner cavity diameter & 35.2 & 89.5 \\
\hline Lead Shielding thickness (ends) & 2.2 & 5.5 \\
\hline Lead Shielding thickness (side) & 1.1 & 2.8 \\
\hline
\end{tabular}

The SARP will demonstrate the capacity of the CASTOR GSF cask to withstand, without generating stress in any material of the CASTOR GSF cask in excess of yield strength, a static force applied to the center of gravity of the CASTOR GSF cask. The static force must have a vertical component of two times the gross weight of the fully loaded CASTOR GSF cask, a horizontal component along the direction in which the vehicle travels of ten times the 


$$
\text { WHC-SD-TP-PDC-032 Rev. } 0
$$

weight of the fully loaded cask, and a horizontal component in the transverse direction of five times the weight of the fully loaded cask.

The SARP will demonstrate that any structural part of the CASTOR GSF cask which could be used for securement must be capable of being rendered inoperable for securing the CASTOR GSF cask during transfer, or must have the strength equivalent required for the tiedown attachments to be used for such transfer applications.

The SARP will demonstrate that each tiedown attachment, which is a structural part of the CASTOR GSF cask, must be designed so that failure of the attachment under excessive load would not impair the ability of the CASTOR GSF cask to meet other requirements of this PDC.

\subsubsection{Lifting Attachments}

The cask lifting points consist of two lifting rings, which are press-fitted into the upper unfinned side surface. The cask is then handled with a special lifting device that engages in the holes of the lifting rings. The design and safety analysis of the cask lifting rings are evaluated based on current onsite lifting requirements. This evaluation is accomplished in the Structural Evaluation section (Part B) of the SARP.

The SARP will demonstrate the capability of lifting attachments for the packaging for lifting three times the total suspended weight without generating a combined stress or maximum tensile stress at any point in the load path in excess of the corresponding minimum yield strength of their materials of construction.

\subsubsection{Venting}

As presently designed, the cask does not vent to the surrounding atmosphere once the primary lid is installed and secured.

\subsubsection{Closure Design and Containment}

Positive closure of the CASTOR GSF cask is achieved through bolting the primary lid to the cask body with 24 cap screws, size M 36 . The secondary lid is fastened with 24 cap screws. Both lids have one metallic and one elastomeric seal which are leak testable.

\subsubsection{Shielding}

The shielding capability of the Castor GSF cask consists of a cylindrical cast-iron cask (GGG $40,220 \mathrm{~mm}$ on the side, $205 \mathrm{~mm}$ on the bottom), with a lead liner (28 $\mathrm{mm}$ on the side, $55 \mathrm{~mm}$ on the bottom) inside. Further shielding is afforded by the canister material and the basket. 
WHC-SD-TP-PDC-032 Rev. 0

\subsubsection{Service Life}

For transportation, the assumed cask lifetime is forty years.

\subsubsection{Chemical and Galvanic Reactions}

The payload of the CASTOR GSF cask will be limited so reactions (e.g., chemical or galvanic reactions) among the components and the cask are minimized.

\subsubsection{Heat Dissipation}

In order to improve heat dissipation, longitudinal fins are arranged on the outside wall of the cask.

\subsubsection{Surface Contamination}

Before transfer, contamination on the external surfaces of the CASTOR GSF cask shall not exceed the limits given in Table 4 .

Table 4. Decontamination Limits.

\begin{tabular}{|l|c|c|}
\hline & \multicolumn{2}{|c|}{ Maximum Permissible Limits } \\
\cline { 2 - 3 } & $\mu \mathrm{Ci} / \mathrm{cm}^{2}$ & $\mathrm{dpm} / \mathrm{cm}^{2}$ \\
\hline $\begin{array}{l}\text { Beta. gamma emitting radionuclides; all radionuclides with half-lives less than ten } \\
\text { days; natural uranium; natural thorium; uranium-235; uranium-238; thorium-232; } \\
\text { thorium-228 and thorium-230 when contained in ores or physical concentrates }\end{array}$ & $10^{-5}$ & 22 \\
\hline All other alpha emitting radionuclides & & \\
\hline
\end{tabular}

Table from 49 CFR 173.443

\subsection{TRANSPORT SYSTEM}

\subsection{Transport Vehicle}

The single CASTOR GSF cask shall be transported by tractor-trailer or railcar either as a closed or open transport vehicle. The SARP will document the requirements of the transport configurations and any modifications that must be performed to allow for the safe onsite interarea transfer of the cask.

\subsubsection{Tiedowns}

The CASTOR GSF cask securement/tiedown system, all modifications to this system (if required) shall be in accordance with the requirements of the following criteria. Tractor-trailer tiedowns shall meet Title 49, Code of Federal Regulations (CFR), Part 393 as paraphrased below. Note: Intermodal 
WHC-SD-TP-PDC-032 Rev. 0

frames or containers may be used and must comply with applicable DOT/ISO Regulations.

\subsubsection{Securement Systems.}

4.3.2.1.1 Application and Scope of the Criteria in This Section. The criteria in Section 4.3.2.1 apply to tiedown assemblies, other securement devices, and attachment or fastening devices that are used with the assemblies and devices, which are used to secure cargo to motor vehicles in transit. A1] devices which are used to secure cargo to the transporter must conform to the criteria in this section.

4.3.2.1.2 Tiedown Assemblies. The aggregate working load limit of the tiedown assemblies used to secure an article against movement in any direction must be at least one-half times the weight of the article.

4.3.2.1.3 Load Binders and Hardware. The strength of the load binders and hardware that are part of, or used with, a tiedown assembly must be equal to or greater than the minimum strength specified for that tiedown assembly in Section 4.3.2.1.2.

4.3.2.1.4 Attachments to the Vehicle. The hook, bolt, weld, or other connector by which a tiedown assembiy is attached to a vehicle, and the mounting place and means of mounting the connector, must be at least as strong as the tiedown assembly when that connector is loaded in any direction in which the tiedown assembiy may load it.

4.3.2.1.5 Winches or Other Fastenings. The anchorages of a winch or other fastening device mounted on a vehicle and used with a tiedown assembly must have a combined tensile strength equal to, or greater than, the strength of the tiedown assembly.

\subsubsection{Blocking and Bracing.}

4.3.2.2.1 Protection Against Longitudinal Movement. The cargo must be secured so that, when the vehicle decelerates at a rate of $20 \mathrm{ft} / \mathrm{s} / \mathrm{s}$ $(6.0 \mathrm{~m} / \mathrm{s} / \mathrm{s})$, the cargo will remain on the vehicle and will not penetrate the vehicle's front-end structure.

4.3.2.2.2 Protection Against Lateral Movement. The cargo must either be securely blocked or braced against the side, sideboards, or stakes of the vehicle or be secured by devices that conform to either of the following:

1. The vehicle must have at least one tiedown assembly that meets the requirements of Section 4.3.2.1.2 for each 101 inear feet ( 3 linear meters) of lading or fraction thereof.

2. The vehicle must have other means of preventing shifting or falling cargo which are similar to, and at least as effective as, the requirement specified in (1).

4.3.2.3 Additional Tiedown Requirements. Consideration shall be given to tiedown methods (such as remote operations or permanent systems integral to 


$$
\text { WHC-SD-TP-PDC-032 Rev. } 0
$$

the packaging and transport vehicle) to maximize the distance and/or minimize the time spent near the payload.

\subsection{GENERAL REQUIREMENTS}

\subsection{TRANSPORTATION EVALUATION REQUIREMENTS}

The SARP shall evaluate all packaging requirements for the transport of Type $B$ radioactive material as required by IAEA. This evaluation shall be based on the existing SAR (GNS 1990). Since many of the documents referenced in the SAR (GNS 1990) are German, and may not be readily available, additional analysis will be performed as necessary to form the basis for the safety evaluations. The use of ductile cast iron will be thoroughly evaluated to ensure safety requirements are met, including the insensitivity of ductile cast iron to brittle fracture.

\subsubsection{Normal Transfer Conditions}

The CASTOR GSF cask shall meet IAEA Safety Series No. 6 for normal conditions of transport and shall have the capacity to retain the contents, limit direct radiation and adequately disperse thermal heat from the payload, and maintain subcriticality during normal transfer conditions.

a. Containment. The CASTOR GSF cask shall prevent the loss or dispersal of the radioactive contents during normal transfer conditions. The payload canister is considered part of the containment system. Containment of the CASTOR GSF cask shall be maintained to $10^{-6} / A_{2}$ per hour during normal conditions of transport.

b. Shielding. Contents of the CASTOR GSF cask shall be transported as a full load. Therefore, the shielding of the CASTOR GSF shall limit the average accessible contact dose rate to $200 \mathrm{mrem} / \mathrm{h}(0.002 \mathrm{~Sv} / \mathrm{h})$. The dose rate at $6.6 \mathrm{ft}(2 \mathrm{~m})$ from the cask surface shall be 7 imited to $10 \mathrm{mrem} / \mathrm{h}$ $(0.0001 \mathrm{~Sv} / \mathrm{h})$. The dose rate at any normally occupied space in the transfer vehicle shall be limited to less than $2 \mathrm{mrem} / \mathrm{h}(0.00002 \mathrm{~Sv} / \mathrm{h})$. Transport of the casks shall fall under exclusive use.

c. Criticality. The amount of fissile material within the CASTOR GSF cask payload (radioactive nuclides - five canisters) is less than $15 \mathrm{~g}$. Consequently, subcriticality is maintained for any arrangement of the cask which fall under fissile excepted quantity.

\subsubsection{Accident Events}

The SAR (GNS 1990), available supporting documents, and additional analyses shall be used to show that the CASTOR GSF Cask meets IAEA Safety Series No. 6 for hypothetical accident conditions. If necessary, a dose consequence and risk analysis will be performed to ensure the packaging system meets the onsite transportation safety requirements (Mercado 1994). 
WHC-SD-TP-PDC-032 Rev. 0

\subsubsection{Thermal}

The CASTOR GSF cask SARP shall ensure the maximum thermal payload currently described in the SAR (GNS 1990) does not compromise the integrity of the cask during normal conditions of transport. Additionally, therma? heat dissipation from the cask payload shall be limited so that the maximum exterior temperature of the cask will be less than $85^{\circ} \mathrm{C}$ (185 ${ }^{\circ} \mathrm{F}$ ) during the hottest Hanford Site day without considering solar insolation. If required, the SARP will also limit the climatic conditions under which the cask may be transported. Both open and closed transport methods will be considered. Based on current information, gas generation is not a concern.

In addition, the SARP will ensure that under hypothetical accident conditions, the integrity of the CASTOR GSF cask is maintained by demonstrating that the cask is able to withstand the thermal test specified by IAEA 1990, Regulations for the Safe Transport of Radioactive Material 1985, IAEA Safety Series 6.

\subsection{AS LOW AS REASONABLY ACHIEVABLE}

The design features of the CASTOR GSF cask shall be consistent with the requirements of the ALARA Program Manual, WHC-CM-4-11. Exposure of personnel to radiological and other hazardous materials associated with the loading, closure, tiedown, transfer, and off-loading of the package shall be minimized.

The Castor GSF cask shielding is designed such that the dose rate is no greater than a maximum of $200 \mathrm{mrem} / \mathrm{h}$ on contact with the package and $10 \mathrm{mrem} / \mathrm{h}$ or less at $2 \mathrm{~m}(6.6 \mathrm{ft})$ from the package. Additionaliy, dose rates in any normally occupied space of the transport vehicle will be below $2 \mathrm{mrem} / \mathrm{h}$.

\subsection{QUALITY ASSURANCE}

QA program requirements for activities such as design, procurement, fabrication, inspection, testing, component handling, and documentation of the CASTOR GSF cask and their components are specified in the SAR (GNS 1990).

To establish a QA plan for the CASTOR GSF cask, a graded approach is used to define the safety class of both the system and individual components of the packaging system. The application of the safety class system is fully documented in Management Requirements and Procedures (MRP) 5.46, WHC-CM-1-3. QA instructions or plans shall be developed for the procurement, fabrication, and inspection of the package based on the assigned safety class of the package. The QA Program Plan for the Hazardous Materials Transportation and Packaging Program, WHC-IP-0705 (WHC 1995), and Standard Engineering Practices (EP) 1.4, WHC-CM-6-1, defines the WHC QA and safety class implementation, respectively, for radioactive material shipping packages. 
WHC-SD-TP-PDC-032 Rev. 0

\subsubsection{System Safety Class}

The transportation safety class of the CASTOR GSF cask was determined by a transportation safety class evaluation included in Section 6.3. This evaluation assumed the total failure of the packaging system and the release of all of its contents to the environment at the worst possible location on the transportation route. For the shipment of the 324 Building vitrified material, the worst case release location is within the 300 Area, $100 \mathrm{~m}$ $(330 \mathrm{ft})$ from the release point.

The safety class evaluation guidelines contained in Nonreactor Facility Safety Ana7ysis Manual, WHC-CM-4-46, Section 9.0, were followed. A worst case event is postulated which results in a dose to the maximum onsite and offsite receptor of $22 \mathrm{rem}\left(2.2 \times 10^{-1} \mathrm{~Sv}\right)$. The onsite and offsite doses are the same because although the roads maybe closed for shipment, the 300 Area is not a public exclusion area. The onsite and offsite receptor locations are therefore both assumed to be $100 \mathrm{~m}$ from the release point. Since the maximum offsite dose is greater than 0.5 rem, the required Safety Class for the CASTOR GSF cask is Safety Class 1.

\subsection{DESIGN FORMAT}

Development of the design drawings, design changes, and other design documentation, if required, shall be in accordance with WHC-CM-6-1, and the Drafting Standards manua1, WHC-CM-6-3.

\subsection{ENVIRONMENTAL COMPLIANCE}

Actions and conditions for the protection of the environment during transfer of the CASTOR GSF cask shall comply with the requirements of the Environmental Compliance manual, WHC-CM-7-5.

\subsection{MAINTENANCE}

The maintenance schedule for the cask shall be in accordance with As Low As Reasonably Achievable (ALARA) principles and the SAR (GNS 1990).

\subsection{REUSE}

The SARP will define guidelines on inspection and maintenance that will a) low the cask to be reused in accordance with WHC-CM-2-14. 
WHC-SD-TP-PDC-032 Rev. 0

\subsection{APPENDICES}

\subsection{REFERENCES}

49 CFR 393, "Protection Against Shifting or Falling Cargo," Code of Federa] Regulations, as amended.

GNS, 1990, Safety Analysis Report CASTOR GSF, GNS B 69/85, Rev. 10, Gesellschaft für Nuklear-Service mbH, Essen, Germany.

Holten, L. K., Jr., and J. E. Surma, 1989, Processing Summary Report: Fabrication of Cesium and Strontium Heat and Radiation Sources, PNL-6790/UC-510, Pacific Northwest Laboratories, Richland, Washington, February 1989.

IAEA, 1990, Regulations for the Safe Transport of Radioactive Material 1985 Edition, IAEA Safety Series No. 6, as amended 1990, International Atomic Energy Agency, Vienna, Austria.

Mercado, J. E., 1994, Report on Equivalent Safety for Transportation and Packaging of Radioactive Materials, WHC-SD-TP-RPT-001, Rev. 0 , Westinghouse Hanford Company, Richland, Washington.

Schmittroth, F. A., 1993, Conversion of ORIGEN2 to Sun Workstations, WHC-SD-NR-SWD-006, Rev. 0-A, Westinghouse Hanford Company, Richland, Washington.

WHC-CM-1-3, Management Requirements and Procedures, Westinghouse Hanford Company, Richland, Washington.

WHC-CM-2-14, Hazardous Material Packaging and Shipping, Westinghouse Hanford Company, Richland, Washington.

WHC-CM-4-11, ALARA Program Manua7, Westinghouse Hanford Company, Richland, Washington.

WHC-CM-4-46, Nonreactor Faci7ity Safety Analysis Manual, Westinghouse Hanford Company, Richland, Washington.

WHC-CM-6-1, Standard Engineering Practices, Westinghouse Hanford Company, Richland, Washington.

WHC-CM-6-3, Drafting Standards, Westinghouse Hanford Company, Richland, Washington.

WHC-CM-7-5, Environmental Compliance, Westinghouse Hanford Company, Richland, Washington.

WHC, 1993, Hanford Solid Waste Acceptance Criteria, WHC-EP-0063, Westinghouse Hanford Company, Richland, Washington. 
WHC-SD-TP-PDC-032 Rev. 0

WHC, 1995, QA Program for the Hazardous Materials Transportation and Packaging Program, WHC-IP-0705, Rev. 1, Westinghouse Hanford Company, Richland, Washington. 
WHC-SD-TP-PDC-032 Rev. 0

6.2 SOURCE TERM INFORMATION FROM THE CASTOR GSF SAR 
WHC-SD-TP-PDC-032 ReV. 0

\section{SAFETY NALYYSIS REFORT}

CASTOR GSF

Report No.

Date (first 1ssue):

Rev. 10

Checked by author:

Released Ey Gis:
GNS $369 / 85$

Decenber 1985

Suly 1990

\section{$\mid \operatorname{lintajs|}$ \\ initialsi}

This report may not be quoted, reproduced in whole or in part, er furnished to third parties except with the affroval of Gis

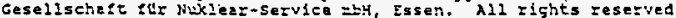
by GNS.

$0-1$ 
1.3 Cask Inventory

A raximug of five stidnless steel cantsters filled with vitrified nuclices are stored and shipped in the CAstor 6sF. The cemposition of the gless and the deslgn.of the canifter is described in wat foljows. Data are taken reat the GSF design principles $\{1-1\}$ and represent the vpper design limit. The werst-case canister invertory have keen taken fnto account with the upper tolerance liofts. Scee of the canister encountered have values markediy below these design lisits, wo that thase loading varlants are also covered.

Th principal dimensiors and welghts of the esF glass cenisters can be found in Fig. $1-1$ and Table 1-7.

$\lambda$ sumary or tre glass eomposition is presented in Table 1-a.

The inventeries as Well is the neat output fer the upger desten lifit, ere given in table $1-9$.

The GSF glass eanixter is to te regarded as a tght contalnment with regard to activity reiease $[1-1]$.

$1-12$ 


\section{WHC-SD-TP-PDC-032 Rev. 0}

Table 1-7. Dixensions and veights, Gsp glass canister.

leight

- without head

- wien head

- Filling

Outslee diameters

- Empty at room terperature

- Fillad (out of round)

Inside diseters

- Enpty at room tempezature

- wall thickness

Weleht

- Total veight

- Veight of gless

- volure of gless

- Density of glass

Dreuing No.: GSF No. E4.52.01.00 a Date: June $3,1 \leq 85$
$2154 \mathrm{mag}$

$1197 \mathrm{~mm}$

$1000 \mathrm{nat}$

$298.5+3=2$

$306 \pm 1$ m

$282.5 \mathrm{~mm}$

$8 \mathrm{ma}$

$250 \mathrm{~kg}$

$168 \mathrm{~kg}$

$60 \mathrm{dn}^{3}$

$2.8 \mathrm{~kg} / \mathrm{dm}^{3}$ 
Tabl* 1-8, Glass composition, GSF glass canister.

\begin{tabular}{|c|c|c|}
\hline Katerial & $\begin{array}{l}\text { Content, } \\
\text { w. } t\end{array}$ & $\begin{array}{l}\text { Density, } \\
\mathrm{g} / \mathrm{Cm}^{3}\end{array}$ \\
\hline $\mathbf{3}$ & 4.673 & 0.1294 \\
\hline 0 & 43.873 & $1.22 \mathrm{ES}$ \\
\hline $\mathrm{Na}$ & 8.834 & 0.2674 \\
\hline$Y_{\mathbf{g}}$ & 0.778 & 0.0218 \\
\hline A & 1.260 & 0.0353 \\
\hline si & 20.674 & 0.5145 \\
\hline $\mathrm{Cl}$ & 0.251 & 0.0012 \\
\hline Ca & 0.879 & 0.0245 \\
\hline II & 0.149 & 0.0012 \\
\hline$C_{2}$ & 0.149 & 0.0042 \\
\hline $\mathrm{Ma}$ & 0.599 & 0.0280 \\
\hline$F_{*}$ & 6.598 & $0.25: 9$ \\
\hline $\mathrm{MI}$ & 0.234 & 0.0068 \\
\hline$s$ & 1.612 & 0.0431 \\
\hline $2 r$ & 0.051 & 0.0016 \\
\hline C. & 5.414 & 0.1515 \\
\hline E. & 1.155 & 0.0324 \\
\hline Le & 1.015 & 0.0284 \\
\hline Nid & 0.510 & 0.0255 \\
\hline Fb & 0.046 & 0.0230 \\
\hline
\end{tabular}

$1-33$ 
WHC-SD-TP-PDC-032 Rev. 0

rable 2-9. Inventory, heat output, 655 glass canlstex.

rax. ectivisy of aded nuclices

- Cesiva-137

$1.20^{16}$ qq $+108=1.1 \cdot 10^{16} \mathrm{~Bq}$

- St:ertilim-to/yttziun-90

$7 \cdot 10^{25} \mathrm{~Bq}+108-7.7 \cdot 2025 \mathrm{Eg}$

Residual cuantitles of actirices (per candster).

- Natural therium alexlde $\mathrm{ThO}_{2}<2$ we. * (based on glass)

- Total plutoniun <39

Nuclide vector, plutontun:

$\mathrm{Pu}-23 \mathrm{~B}$

Pu-239

Fu-240

Eu-241

$8 \sqcup-242$

- total uranilir. $\quad 20.0$ g

0.34 wt. *

90.00 ve.

8.17 wะ. *

0.77 wt. *

0.29 4t.

Nuclice vectcr, tranium:

$U-234$
$U-235$
$U-226$

$0.00859 \mathrm{Wt}$.

0.87453 Wt.

0.06831 we.

$\$ 9.03$ ut.

$U-238$

$<0.19$

- Arericius=-242

$<2.0 \mathrm{~g}$

- inericium-243/244

ieat outrus

$2063 \mathrm{~W} /$ canistes + $20 \mathrm{H}=2285 \mathrm{~W}$

Dese zate at canister surzece

Gama: $\quad 5 \cdot 10^{5} \mathrm{R} / \mathrm{h}+10 \mathrm{r}-5.5 \cdot 10^{5} \mathrm{R} / \mathrm{h}$

Neutrons: Nene

$2-34$ 


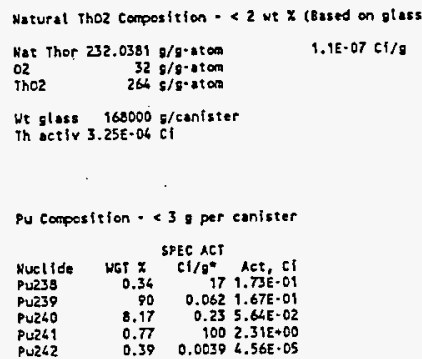

Max. hetivity of hdded Huelides

\begin{tabular}{|c|c|}
\hline $\operatorname{cs} 137$ & $9 E+1689$ \\
\hline
\end{tabular}




\section{WHC-SD-TP-PDC-032 Rev. 0}

\section{ORIGENR INPUT AND PERTINENT OUTPUT}

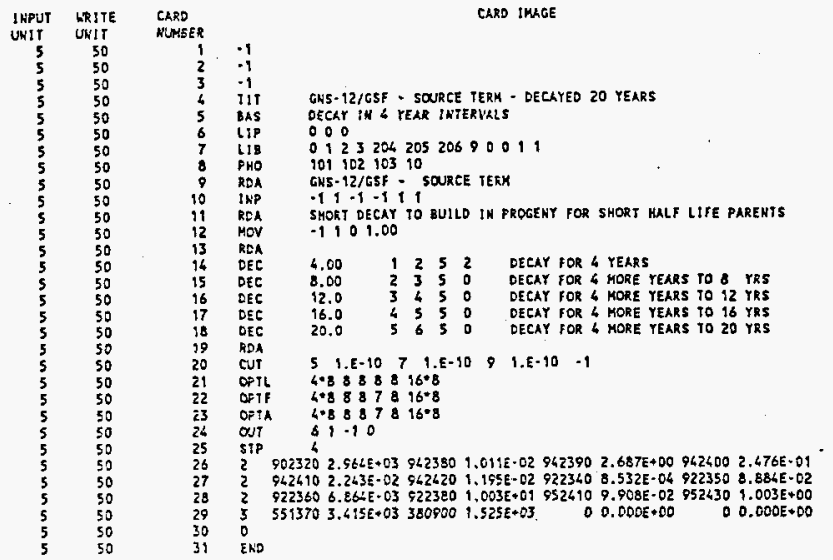

- gKS.12/GSF - SOURte iekH - oEcayed 20 yeaks

ACTIHYOES+DAUCHTES

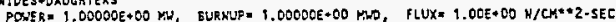

7 SURMRT TAELE: RADICACTIVITY, CURJES OECAY IN 4 YEAR INTERVAL $0.0005 * 009.9 E 9 E+054.7 \$ 6 E-05 \quad 7.024 E-05 \quad 8.582 E-05 \quad 9.032 E-05$ $0.000 E+00$ 5.67EE-05 $1.355 E-061.955 E \cdot 042.3895 \cdot 042.681 E \cdot 04$

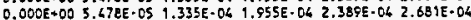
$0.000 E+00 \quad 5.672 E-051.335 E .04$ 1.95SE.04 2.389E-06 2.681E.04 $0.000 E+00 \quad 5.67 \mathrm{EE}-05 \quad 1.335 \mathrm{E}-04 \quad 1.955 \mathrm{E}-042.389 \mathrm{E}-06 \quad 2.681 \mathrm{E}-04$ $0.000 E+00 \quad 5.478 E-05 \quad 1.335 E-06 \quad 1.555 E-062.389 E-042.681 E-04$ $0.000 E+00 \quad 5.67 \mathrm{gE}-05$ 1.335E-06 1.553E-04 2.389E-04 2.681E-04 $0.000 E=001.902 E-04 \quad 1.831 E+04 \quad 2.312 E-042.631 E+04 \quad 2.841 E+04$ $0.000 E+00 \quad 1.102 E+049.231 E-062.312 E-042.631 E-042.861 E-04$ $0.0005+005.47 E E-05+334 F .06$ 1.553E-06 2.386E-06 2.678E-06

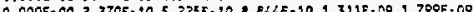

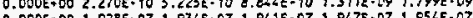
$3.252 E-04 \quad 3.252 E-04 \quad 3.252 E-04 \quad 3.252 E-06 \quad 3.252 E-043.252 E-04$ $0.000 E+00 \quad 3.3736 .06 \quad 3.373 E+06 \quad 3.373 E-06 \quad 3.373 E-063.373 E-06$ $0.000 E+00$ 4.48EE-07 9.05EE-07 1.351E.08 1.861E-06 2.3L6E.06 $0.000 E-00 \quad 3.373 E-06 \quad 3.373 E-05 \quad 3.373 E-053.373 E-06 \quad 3.373 E-06$ $0.000 E+004.385 E-09$ 4.385E-09 $4.385 E-09$ 4.385E-09 4.385E-09 $5.333 E .067 .2665 .069 .1395 .051 .055 E .051 .271 E-051.641 E .05$ $1.821 E-07$ 1. 4.263E-07 6.505E-07 6.57SE-07 4.663E-07 4.710E-07 4.776E-07 $0.000 E+004.67 E E-053.858 E-053.183 E-052.625 E-052.965 E-05$ $3.373 \mathrm{E}-06 \quad 3.373 \mathrm{E}-06 \quad 3.373 \mathrm{E}-06 \quad 3.373 \mathrm{E}-06 \quad 3.373 \mathrm{E} .06 \quad 3.373 \mathrm{E} .06$ $0.000 E+00 \quad 6.484 E-079.656 E-079.381 E-051.861 E-062.3468-06$ $0.000 E-002.000 E-011.995 E-019.85 E E-011.997 E-011.997 \mathrm{E}-01$ 1.731E-01 1.67EE-01 1.625E-01 1.575E-01 1.526E-01 1.47EE-01 $1.671 \mathrm{E} .011 .671 \mathrm{E} .011 .671 \mathrm{E}-011.671 \mathrm{E} .011 .671 \mathrm{E} .011 .6 \mathrm{TIE} .01$ $5.644 E-025.642 E-025.639 E-02 \quad 5.437 E-025.635 E-62 \quad 5.632 E-02$ $2.312 E+001.507 E+00 \quad 1.573 E+001.257 E+00 \quad 9.070 E+00$ B.E2TE-01 


\section{WHC-SO-TP-PDC-032 ReV. 0}

PU262 6.565E-05 4.565E-05 4.564E-05 4.564E-05 4.564E-05 4.564E-05

NR241 3.602E-01 3.515E-01 3.603E-01 3.671E-01 3.723E-01 3.752E-09

N263 2.000E-01 2.000E-01 9.999E-01 1.99AE-01 1.997E-01 1.997E-01

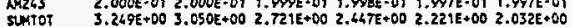

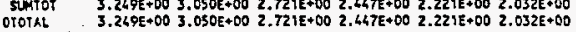




\subsection{SAFETY CLASS EVALUATION}

ENGINEERING ANALYSIS

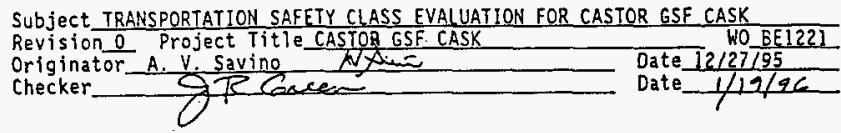

\section{Objectives:}

This engineering enalysis documents a transportation safety class evaluation for the CASTOR GSF Cask which will be used to transport canisters containing activated vitrified glass material from the 324 Building in the 300 Area to the 200 Kest Area.

\section{References:}

60 FR 50319, 1995, "Hazardous Materials, Transportation Regulations; Compatibility With Regulations of the International Atomic Energy Agency (IAEA); Final Rule," 49 CFR Part 171, Federal Register, Vol. 60, No. 188, PD. 50319-50325.

DOE, 1994, Airborne Release Fractions/Rates and Respirable Fractions for Nonreactor Nuclear Facilities, DOE-HOEK-3010-94, U. S. Department of Energy, Washington, D. C.

Hey, B. E., 1995a, GXQ 4.0 Program Users' Guide, KHC-SD-GN-SWD-30002, Rev. 1, Westinghouse Hanford Company, Richland, Washington.

Hey, B. E., 1995b, GXQ 4.0 Program Verification and Validation, HHC-SD-GN-SWD-30003, ReV. 1, Westinghouse Hanford Company, Richland, Washington.

Napier, B. A., et al., December 1988, GEMII - The Hanford Environmental Radiation Dosimetry Software System, Pacific Northwest Leboratory, Richland, Hashington, PNL-6584 Vol. 1, UC-600.

NRC, 1982, Atmospheric Dispersion Models for Potential Accident Consequence Assessments et Nuclear Power Plants, Regulatory Guide 1.145, U.S. Nuclear Regulatory Comission, Washington, D.C.

Schmittroth, 1993, Conversion of ORIGE/l2 to Sun Workstations, WHC-SD-NR-SWD006 Rev. 0-A, hestinghouse Hanford Company, Richland, Washington.

HiHC-CM-4-46, Nonreactor Facility Safety Analysis Manual, hestinghouse Hanford Company, Richland, Washington.

\section{Results and Conclusions:}

The safety class evaluation quidelines contained in WHC-CM-4-46, Section 9 , were followed. A k'orst case event is postulated which results in a dose to the maximum onsite and offsite receptor of 22 ren $\left(2.2 \times 10^{-1} \mathrm{~Sv}\right)$. The onsite 
WHC-SD-TP-PDC-032 Rev. 0

- GNS-12/GSF - SQUREE TERK - DECAYEO 20 YEARS

Fisston

PRooucts

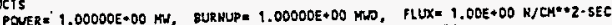

0

7 SLPURY TABLE: RADIOACTIVITY, CURIES

DECAY IN 6 YEAR TWTERVACS

0.05 6.0Y 6YR 12.0YR 16.0YR 20.0YR

SR $90 \quad 2.089 E+05 \quad 1.292 E+05 \quad 1.720 E+05 \quad 1.564 E+05 \quad 1.622 E+05 \quad 1.253 E+05$

$\times 90 \quad 0.000 E+001.892 E+0591.721 E+051.564 E+051.422 E+051.293 E+05$

CS137 $2.072 E+052.7005+052.470 E+052.252 E+052.053 E+051.872 E+C 5$

$0.000 E+002.563 E+05 \quad 2.337 E+05 \quad 2.131 E+05 \quad 1.962 E+05 \quad 1.771 E+05$

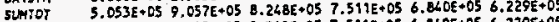

OTOIAL $5.053 E+059.057 E+058.248 E+057.511 E+056.840 E+056.229 E+05$ 
WHC-SD-TP-PDC-032 ReV. 0

ENGINEERING ANALYSIS

SUbject IRANSPORTATION SAFETY CLASS EVALUATION FOR CASTOR GSF CASK

Revisjono Project Title CASTOR GSF CASK WOBEI22l

Originator A. Y. Savino Date_l2/27/95

checker

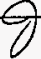

Date_.1/4/96

and offsite doses are the same because several 300 Area locations have roads which are accessible to the public. The onsite and offsite receptor locations are therefore both assumed to be $100 \mathrm{~m}$ from the release point. Since the maximum offsite dose is greater than $0.5 \mathrm{rem}$, the required transportation safety class for the CASTOR GSF cask is transportation safety class 1.

IV. Engineering Evaluation:

\section{i.o Introduction}

The CASTOR GSF cask is designed to hold five activated glass canisters. A glass canister is a container with vitrified radioactive materlals manufactured at Hanford. These casks will be transported from the 300 Area to the 200 West Area. An evaluation is necessary to determine the required transportation safety class for the cask.

\section{2:0 Source Term}

Table 1 lists the source term for the CASTOR GSF cask which was deveioped in section 2 of the PDC. 
WHC-SD-TP-PDC-032 Rev. O

ENGINEERING ANALYSIS

SUbject TRANSPORTATION SAFETY CLASS EVALUATION FOR CASTOR GSF CASK Revision D Project Title CASTOR GSF CASK Originator A. V. Savino Checker. AVI C) Conen

\begin{tabular}{|c|c|c|}
\hline Muclide & $\begin{array}{c}\text { single canisser } \\
\text { Activity. Gi }\end{array}$ & $\begin{array}{l}\text { Moximum Eask } \\
\text { Aetivity, ci }\end{array}$ \\
\hline$\$ R 90$ & $2.1 \mathrm{E}+05$ & $1.1 k+06$ \\
\hline Y9O & $2,1 E+05$ & $1.1 E+08$ \\
\hline $\operatorname{cs} 137$ & $3.0 E+05$ & $1.5 E+C S$ \\
\hline EA137m & 2. $8 \mathrm{E}+0.5$ & $1.45+06$ \\
\hline $\mathrm{TL208}$ & $1.2 \varepsilon \div 04$ & 6.05 .04 \\
\hline FE212 & $3.3 E \cdot 04$ & 1.7E-03 \\
\hline 81212 & $3.3 E-04$ & $1.7 E-03$ \\
\hline PO212 & 2.15-04 & $1.1 E \cdot 03$ \\
\hline $\mathrm{PO} 216$. & $3.3 \mathrm{E} \cdot 04$ & $1.7 \mathrm{E} .03^{\circ}$ \\
\hline RN220 & $3.3 E-04$ & $1.7 E-03$ \\
\hline $5 k 224$ & $3.3 E+04$ & $1.7 E-03$ \\
\hline E<L228 & $3.3 E-04$ & $1.7 \mathrm{E}-03$ \\
\hline$A: 228$ & $3.3 E-04$ & $1.7 \mathrm{E}-03$ \\
\hline$T H \leq 28$ & $3.3 \mathrm{E}=04$ & $1.7 \mathrm{E} \cdot 0 \mathrm{~s}$ \\
\hline $1: 231$ & $1.95-07$ & $9.5 \mathrm{E} \cdot 07$ \\
\hline in.32 & $3.3 E-04$ & $1.7 \mathrm{E}-03$ \\
\hline 911236 & $3.6 E-06$ & $1.7 \mathrm{E} \cdot 05$ \\
\hline FR23:in & $3.4 E-0 S$ & $1.7 \mathrm{E}-\mathrm{GS}$ \\
\hline 0234 & $5.3 E+06$ & $2.7 \mathrm{E} .05$ \\
\hline U235 & $1,9 \mathrm{~g} \cdot 07$ & $9.5 E-07$ \\
\hline 4236 & 4.4E:07 & 2.25 .06 \\
\hline U237 & $5.5 E-05$ & $2.8 \mathrm{E}-04$ \\
\hline 4238 & $3.4 E-06$ & $1.7 \mathrm{E} .05$ \\
\hline$x \neq 230$ & $2.0 E+01$ & $1.0 E+00$ \\
\hline PU238 & $1.7 E-01$ & $8.5 E-01$ \\
\hline PUÉ39 & $1.7 \mathrm{E}-0$. & $8.5 E-01$ \\
\hline PU240 & $5.6 E-02$ & 2. $8 \mathrm{E} \cdot 0 \mathrm{O}$ \\
\hline Puz4 & $2.3 \varepsilon+00$ & $1.2 E+01$ \\
\hline PUZLZ & $4.6 E-05$ & $2.3 \pm \cdot 04$ \\
\hline AN261 & $3.4 \mathrm{E}-01$ & 1. $7 \mathrm{E}+00$ \\
\hline 24243 & $2.0 \mathrm{E}-01$ & $1.0 \mathrm{E}+00$ \\
\hline $10141 \mathrm{~s}$ & $1.0 E+06$ & $5.15+05$ \\
\hline
\end{tabular}

assueses a naximum of $\$$ eanisters will be looded in the castor Gsf cask, 
ENGINEERING ANALYSIS

SUbject TRANSPORTATION SAFETY CLASS EVALUATION FOR CASTOR GSF CASK

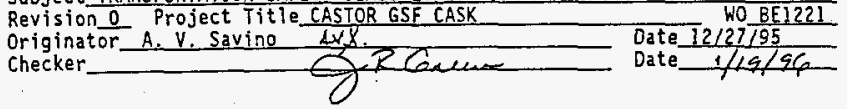

\subsection{Analys is}

The safety class evaluation quidelines contained in WHC-CM-4-46, Section 9, were followed. A worst case airborne release fraction was determined based on a review of the potential accident scenarios which the package may experience.

The ARF and RF were calculated using a formula contained in DOE (1994), Free-Fall Spill and Impaction Stress for Nonmetallic or Composite Solids. This formula is associated with "fragmentation of an aggregate solid that can undergo brittle fraction." It is assumed for this analysis that an event occurs where the package is breached by an external force causing the vitrified material to be released and impact the ground. This impact causes fragmentation of the material at risk and subsequent release to the environment. The formula given is as follows:

$$
A R F \times R F=(A)(P)(g)(h)
$$

where:

$$
\begin{aligned}
& \text { ARF } \times \text { RF }=\text { (Airborne Release Fraction)(Respirable Fraction) } \\
& A \text { - empirical correlation, } 2 \times 10^{-11} \mathrm{~cm}^{3} \text { per } \mathrm{g}-\mathrm{cm}^{2} / \mathrm{s}^{2} \\
& \mathrm{p} \quad \text { - specimen density, g/ } \mathrm{cm}^{3} \\
& 9 \quad \text { gravitational acceleration, } 980 \mathrm{~cm} / \mathrm{s}^{2} \text { at } 5 e a \text { level } \\
& \text { h - fall height, cri. }
\end{aligned}
$$

A fall height of $1 \mathrm{~m}$ is assumed for this analysis. This is a typical height used for objects falling off of a truck. The density of the waste is $2.8 \mathrm{~g} / \mathrm{Cc}$, which results in an ARF $\times$ RF of $5.5 \times 10^{-6}$. This ARF $\times$ RF is applied to the material at risk, which is conservatively assumed to be the entire cask inventory, to obtain the quantity of radioactive material that is made airborne for the postulated accident scenario. The accident release quantities are listed in Table 2 .

A fire scenario was also considered, but based on information contained in DOE (1994), Therme) Stress - Vitrified Waste (Section 4.3.1.1), "any release under industrial-type fire conditions appears to be negligible." Therefore, no airborne release fire scenario is included in this analysis. 
WHC-SD-TP-PDC-032 Rev. 0

ENGINEERING ANALYSIS

SUbject TRANSPORTAIION SAFETY CLASS EVALUATION FOR CASTOR GSF CASK

Revision 0 Project Title CASTOR GSF CASK

Originator A. V. Savino

Checker.

Date $12 / 27 / 95$

Date $1 / 19 / 96$

\begin{tabular}{|c|c|c|}
\hline Muet ide & $\begin{array}{l}\text { Maxitum Cask } \\
\text { Activity, Ci }\end{array}$ & $\begin{array}{l}\text { Lec ident Releass } \\
\text { Cuantity. Ci }\end{array}$ \\
\hline SR9O & $1.1 E+06$ & 6. $1 E \div 00$ \\
\hline$r 90$ & $1.1 E+06$ & $5.1 E+00$ \\
\hline C5137 & $1.5 \mathrm{E}+06$ & $8.3 E+00$ \\
\hline DA137n & $1.4 E+06$ & $=7.7 \mathrm{E}+00$ \\
\hline TL2OS & 6.0E-06 & $3.3 E-09$ \\
\hline F5212 & 1. $7 E-03$ & $9.4 \mathrm{E}=09$ \\
\hline \#1212 & $1.7 E-03$ & $9,4 E \cdot 09$ \\
\hline $\mathrm{PO212}$ & $1.1 E-03$ & $6.1 E-09$ \\
\hline P0216 & $1.7 E .03$ & $9.46-09$ \\
\hline RN220 & $1.7 E-03$ & $9.4 E-09$ \\
\hline RA2ZL & $1.7 \mathrm{E}-03$ & $9.6 \mathrm{E}-09$ \\
\hline RAZZS & $1.7 \mathrm{E} \cdot 03$ & $9,4 \mathrm{E}=09$ \\
\hline$A C 228$ & $1.7 \mathrm{E}-03$ & $9.4 \mathrm{E} \cdot 09$ \\
\hline TH:28 & 1.75 .05 & $5, i \bar{c} \cdot 0 \xi$ \\
\hline TH231 & $9.5 E-07$ & $5.2 E-12$ \\
\hline TK232 & $1.7 E-03$ & $9.4 \mathrm{E}-09$ \\
\hline in234 & $1,7 \varepsilon-05$ & $9.4 E \cdot 91$ \\
\hline PA236m & $1.7 \mathrm{E} \cdot 05$ & $9.4 \mathrm{E}-11$ \\
\hline U234 & $2.7 \mathrm{k}-05$ & $1.5 \mathrm{E}-10$ \\
\hline \pm 235 & 9.SE-07 & 5. $2 E-12$ \\
\hline U256 & 2.2E-06 & $1.2 E-11$ \\
\hline U237 & 2. BE- 04 & $1.5 \varepsilon-09$ \\
\hline U238 & $1.7 \mathrm{k}-05$ & $9.4 \mathrm{E}-11$ \\
\hline KP239 & $1.0 \mathrm{E} \cdot 00$ & $5.5 \mathrm{E} \cdot 0 \mathrm{~S}$ \\
\hline Py238 & 8.5E-09 & 4.7E-06 \\
\hline PU239 & B. $5 E-01$ & $4.7 \mathrm{E}-06$ \\
\hline Pu2 20 & 2. $8 \mathrm{E}-01$ & $1.5 E .06$ \\
\hline Pu241 & $1.2 \mathrm{E}+01$ & $8.6 E \cdot 05$ \\
\hline PUI262 & $2.3 E \cdot 04$ & $1.3 \mathrm{E}-09$ \\
\hline AM261 & $1.7 \varepsilon+00$ & $9.6 E-06$ \\
\hline $2 M 243$ & $1.0 \mathrm{E}+00$ & $5.5 E \cdot 06$ \\
\hline TOTALS & 5. $2 E+0 S$ & 2. $E E+01$ \\
\hline
\end{tabular}

- Arsunes a maximun of 5 canisters wil be lcoded in the castch csF cosk.

coleutsted using the raximm cask sctivities from colum I and epplying the ARF $\times$ RF value of $5.5 \times 10^{\circ}$ to all rodionuelides. 
WHC-SD-TP-PDC-032 Rev. 0

\section{ENGINEERING ANALYSIS}

SUbject TRANSPORTATION SAFETY CLASS EVALUATION FOR CASTOR GSF CASK $\begin{array}{ll}\text { Revision } O \text { Project Title CASTOR GSF CASK } & \text { WOBE1221 } \\ \text { Originator A. V. Savino Ad } & \text { Date 12/27/95 } \\ \text { Checker } & \text { Date } 1 / 15 / 26\end{array}$

\section{Discussion of Atmospheric Relative Concentration Value $\left(x / 0^{\prime}\right)$}

After the radioactive material becomes airborne, it is transported downwind and inhaled by onsite workers or the public. The concentration of this material is reduced, or diluted, es it is being transported due to atmospheric mixing and turbulence. An atmospheric relative concentration value $\left(x / Q^{\prime}\right)$ is used to characterize the dilution of the airborne contaninants during atmospheric transport and dispersion. It is equal to the timeintegrated normalized air concentration at the receptor. $X / Q^{4}\left(5 / m^{3}\right)$ represents the dilution of an airborne contaminant caused by atmospheric mixing and turbulence. $X / Q^{\prime}$ is a function of the atmospheric conditions (i.e., wind speed, stability class) and the distance to the receptor.

Bounding $x / Q^{\prime}$ values are generated consistent with the methods described in Atmospheric Dispersion Models for Potential Accident Consequence Assessments at Wuclear Power Plants, Regulatory Euide 1.145 (NRC 1982). Since atmospheric conditions fluctuate, a bounding atmospheric condition is determined to be that condition that causes a downwind concentration of airborne contaminants that is exceeded only a small fraction of time because of weather fluctuations. Regulatory Guide 1.145 defines this fraction of exceedance as $0.5 \%$ for each sector or $5 \%$ for the overall Hanford site. The Hanford site is broken up into 16 sectors that represent 16 compass directions (i.e., S, SSW, SW, ..., ESE, SE, SSE). $X / Q^{\prime}$ values are generated for weather conditions that result in downwind concentrations exceeded only $0.5 \%$ of the time in the maximum sector or $5 \%$ of the time for the overall site. These $x / Q^{\prime}$ values are also referred to as $99.5 \%$ maximum sector and $95 \%$ overail site $X / Q^{\prime}$ values. The greater of these two values. is called the bounding $X / Q^{\prime}$ value and is used to assess the dose consequences for accident scenarios. The bounding $X / Q$ ' value represents minimum dispersing conditions that result in maximun downwind concentrations (i.e., concentrations exceeded only a very small fraction of the time). This $X / Q^{\prime}$ value will therefore result in very conservative estimates of accident consequences.

The $X / Q^{\prime}$ values in this report were generated using the GXQ computer program, Version 4 (hey 1995a, 1995b). The meteorological data used by GXQ are in the form of joint frequency tabies. The joint frequency data are the most recent data available; they are nine-year averaged data (1983-1991) from the Hanford site meteorology towers. As mentioned above, the $X / Q^{\prime}$ values are generated using the methods described in Regulatory Guide 1.145 for a ground release with no credit taken for plume rise, plume meander, plume depletion, or any other models. This is conservative because all of these models reduce the airborne concentration at the downwind receptor locations. 
WHC-SD-TP-PDC-032 Rev. 0

ENGINEERING ANALYSIS

Subject TRANSPORTATION SAFETY CLASS EVALUATION FOR CASTOR GSF CASK

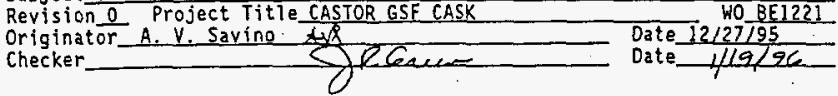

The CASTOR GSF packages will be transported from the 300 Area to the 200 Area. Therefore, $x / Q^{\prime}$ values for the maximum onsite receptor (assumed to be located $100 \mathrm{~m}$ from the release point) were calculated using the joint frequency data for these two areas (i.e., 200, 300 Areas), and the highest value was selected. The highest $X / Q^{\prime}$ value of $4.2 \times 10^{-2} \mathrm{~s} / \mathrm{m}^{3}$ occurs for the 300 Area.

The worst case offsite receptor ( $f . e .$, highest $X / Q^{\prime}$ ) will be located in the 300 Area due to the short distances between the potential transport routes and an offsite receptor. Several 300 Area locations have roads which are accessible to the public. It is conservatively assumed for this analysis that the offsite receptor is iocated $100 \mathrm{~m}$ from the release point in any compass direction. The maximum onsite and offsite receptor $x / Q^{\prime}$ value will therefore be the same, and since the highest $x / Q^{\prime}$ occurs for the 300 area, the maximum offsite $x / Q^{\prime}$ value is $4.2 \times 10^{-2} \mathrm{~s} / \mathrm{m}^{3}$. The titles of the joint frequency files used by $G \times Q$ are listed below.

200 AREA (HMS) - 10 M - Pasquill A - G (1983 - 1991 Average)

300 AREA - 10 M - PasquilT A - G (1983 - 1991 Average)

\section{Inhalation \& Submersion Dose Calculations}

The GENII computer code Version 1.485 (Nepier 1988) was used to calculate the inhalation and submersion dose for the maximum onsite and offsite receptors using the $x / 0^{\circ}$ value mentioned in the previous paragraph. The GENIl input deck is listed in Attachment 1 . The "Worst Case" solubility class library in GENII was selected since the form of the radioactive material is not known with a high degree of certainty. This solubility class is the most conservative library used in GENII. The GENII libraries used were as follows:

GENII Default Parameter Values (28-Mar-90 RAP)

Radionuclide Library - Times $<100$ years (23-July-93 PDR)

External Dose Factors for GENII in person Sv/yr per Bq/n (8-May-90

Worst-Case 5olubilities, Yearly Dose Increments (23-Jul-93 POR)

The Effective Dose Equivalent (EDE) for the inhalation and submersion pathways is $22 \mathrm{rem}\left(2.2 \times 10^{-1} \mathrm{SV}\right)$ for the maximum onsite and offsite receptors at $100 \mathrm{~m}$. The inhalation dose contribution to the EDE is based on a 50 year dose commitment period. Table 3 summarizes the results. Note that ${ }^{90} \mathrm{Sr} /{ }^{90} \mathrm{Y}$ contribute $82 \%$ to the total dose, and ${ }^{133} \mathrm{Cs}$ contributes $17 \%$ to the total dose. 
WHC-SD-TP-PDC-032 ReV. 0

ENGINEERING ANALYSIS

SUbject TRANSPORTATION SAFETY CLASS EVALUATION FOR CASTOR GSF CASK

Revision 0 Project Title CASTOR GSF CASK WO BE1221

originator A, $V$. Savino A,S

checker.

Date $1 2 / 2 7 \longdiv { 1 9 5 }$

O

Date $1 / 15 / 402$

\begin{tabular}{|l|r|r|}
\hline Table 3: Sumary of Inhalation and Submersion Dose, rem \\
\hline Whole Body EOE & $\begin{array}{c}\text { Maximum Onsite } \\
\text { Receptor at } 100 \mathrm{~m}\end{array}$ & $\begin{array}{c}\text { Maximum Offsite } \\
\text { Receptor at } 100 \mathrm{~m}\end{array}$ \\
\hline
\end{tabular}

Note: 100 rem $=1 \mathrm{SV}$

\subsection{Conclusion}

The maximum offsite dose of $22 \mathrm{rem}\left(2.2 \times 10^{-1} \mathrm{SV}\right)$ is greater than 0.5

rem. Therefore, the required transportation safety class for the CASTOR GSF cask is transportation safety class 1. 
WHC-SD-TP-PDC-032 Rev. 0

ENGINEERING ANALYSIS

SUbject TRANSPORTATION SAFETY CLASS EYALUATION FOR CASTOR GSF CASK

Revision 0 Project Title_CASTOR GSF CASK

Originator A. V. Savino Ald

checker

?)

WO BEl22]

Date $12 / 27 / 95$

Date $\frac{1 / 19 / 96}{1 / 96}$

Attachment 1

GENII INPUT FILE

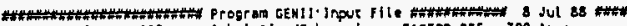
Pirle: Onsite it $100 \mathrm{~m}$ - inholationsutmersion - CAstor t5f - 300 Area ISHMLIG-AIR, AC

created on 01-22-1990 st 07:30

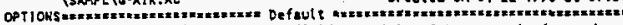

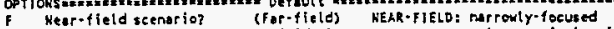

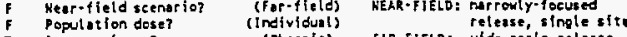

I Acute release? (Chrosic)

Maxifinn Individual cíta set used

FAR-FIELD: Wide-scale release,

Complete

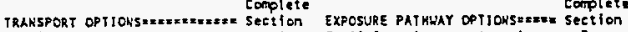

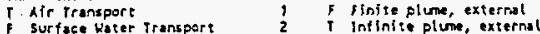

- Blotic Transpott (near-field) 3,6 f Ground, external

f Haste form Degradation (near) 3,6 pecreation, exiernol

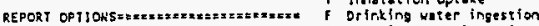

1 Report $A E D E$ only

F Drinking water ingestion

Repert by rectionuclide

F Terrestrial foods ingestion

Report by exposure pathiney

f Aninal produce ingestion

F Inacvertent soil ingestion

- Debug report on screen

INYENTOKY

4 Inventory input activity units: (1-pc| $2-u c|3+m c|$ \&-fl 5-EQ)

- surface seil source units (1. $\mathrm{m2} 2=\mathrm{a3} 3 \cdot \mathrm{kg})$

Equilibriun question gaes here

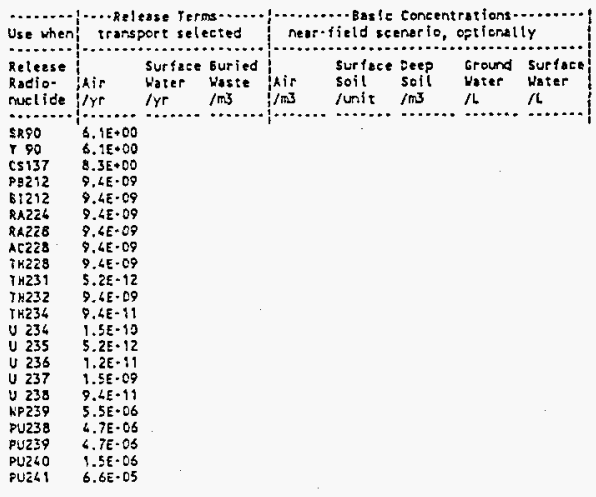


WHC-SD-TP-PDC-032 Rev. 0

ENGINEERING ANALYSIS

SUbject TRANSPORTATION SAFETY CLASS EVALUATION FOR CASTOR GSF CASK

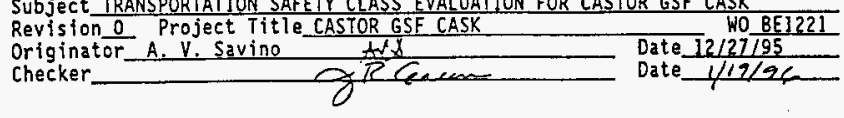

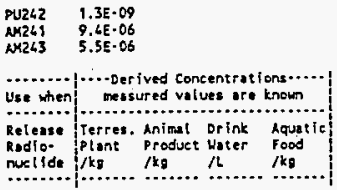

TIME

1 intake ends after (yr)

30 Dose ealc, ends ofter ( $y r)$

1 Releuse ends after $(y t)$

o No. of years of air depesition prfor to the intake period

- Ho. of years of irrigation water depesition prior to the intake perfod

FRR-FIELD SCEKARIOS (IF POPULATIOH DOSE)

o Definition option: T.Use population grid in flle POP.lk

0 2-Use sotat entered on this line

MERR-F1ELD SCEKLRTOS

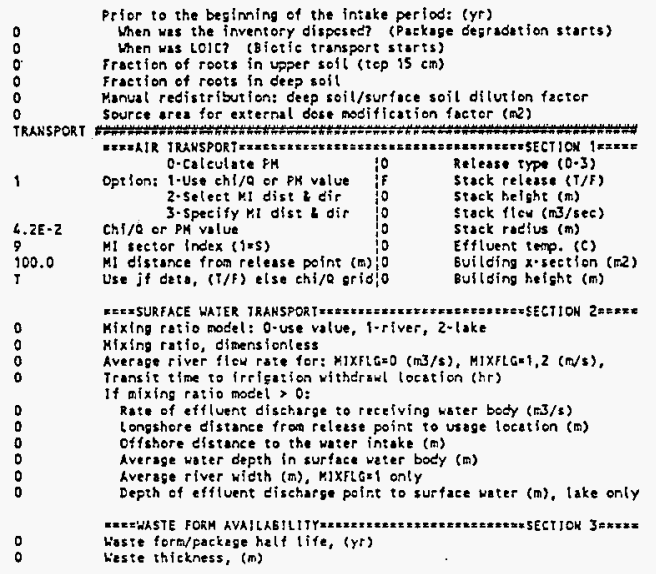




\begin{tabular}{|c|c|c|c|c|c|c|c|c|}
\hline $\begin{array}{l}0.0 \\
0.0 \\
0.0 \\
0.0\end{array}$ & $\begin{array}{l}0.0 \\
0.0 \\
0.0 \\
0.0\end{array}$ & $\begin{array}{l}00+30^{\circ} 0 \\
00+30^{\circ} 0 \\
00+30^{\circ} 0 \\
00+30^{\circ} 0\end{array}$ & $\begin{array}{l}0.0 \\
0.0 \\
0.0 \\
0.0\end{array}$ & $\begin{array}{l}0.0 \\
0.0 \\
0.0 \\
0.0\end{array}$ & $\begin{array}{l}0.0 \\
0.0 \\
0.0 \\
0.0\end{array}$ & $\begin{array}{l}0 \\
0 \\
0 \\
0\end{array}$ & $\begin{array}{l}00^{\circ} 0 \\
00.0 \\
00.0 \\
00.0\end{array}$ & 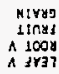 \\
\hline $2 x / 5 x$ & is & an/sy & 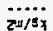 & 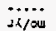 & JK/W & : & pe & 3dil \\
\hline 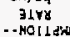 & $\begin{array}{l}\text { and } \\
15 \times 02.4\end{array}$ & $\begin{array}{r}\text { kel12n } \\
\text { - coyd }\end{array}$ & 973เ & $\operatorname{lin}_{-\infty}$ & $\begin{array}{l}\text { alry } \\
\text { |roigy! }\end{array}$ & 5 & $\begin{array}{l}\text { Jxil } \\
\text { norg }\end{array}$ & $\infty 0_{1}$ \\
\hline
\end{tabular}

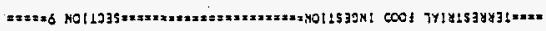

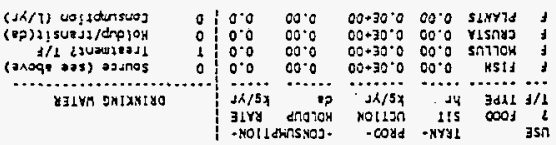

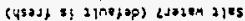

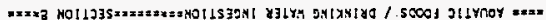

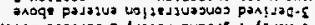

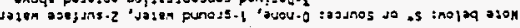

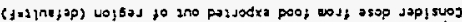

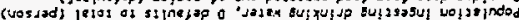
(uostad) lejor oz silnz

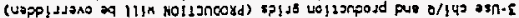
Lolismposd weptiun esn-z

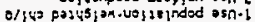

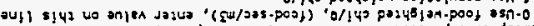

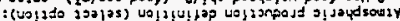

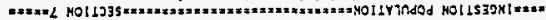

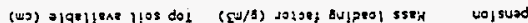

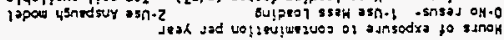

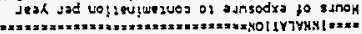

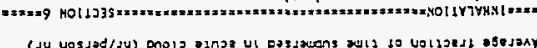

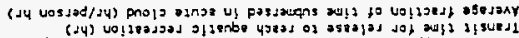

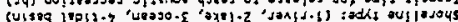

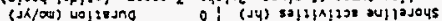

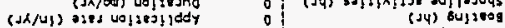

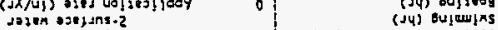

salem oxisins 2 $(1 / 1): 4301$ suoj

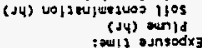

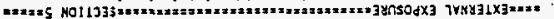

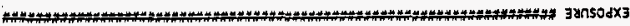

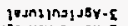

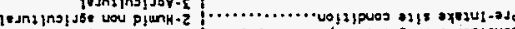

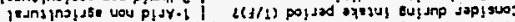

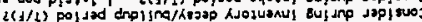

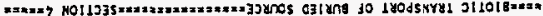

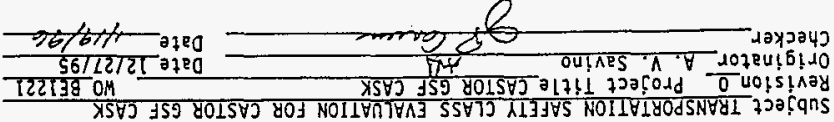

SISᄉTษN 
WHC-SD-TP-PDC-032 Rev. 0

ENGINEERING ANALYSIS

SUbject TRANSPORTATION SAFETY CLASS EVALUAIION FOR CASTOR GSF CASK Revision 0 Project Title CASTOR GSF CASK Originator A.V. Savino ANA

checker

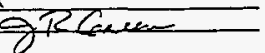
Date_12/27 195

W0 BE1221 Date $\frac{1 / 14 / 9 C}{1 / 4}$

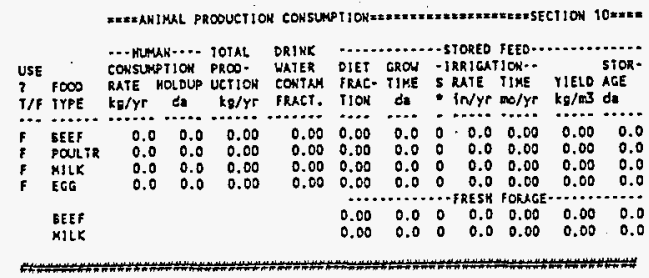




\section{DISTRIBUTION SHEET}

\begin{tabular}{|c|c|c|c|c|c|}
\hline \multirow{2}{*}{$\begin{array}{l}\text { To } \\
\text { Distribution }\end{array}$} & \multirow{2}{*}{\multicolumn{3}{|c|}{$\begin{array}{l}\text { From } \\
\text { Packaging Engineering }\end{array}$}} & \multicolumn{2}{|c|}{ Page 1 of 1} \\
\hline & & & & \multicolumn{2}{|c|}{ Date $03 / 08 / 96$} \\
\hline \multirow{2}{*}{\multicolumn{4}{|c|}{$\begin{array}{l}\text { Project Title/Work Order } \\
\text { CASTOR GSF Packaging Design Criteria (WHC-SD-TP-PDC-032) }\end{array}$}} & \multirow{2}{*}{\multicolumn{2}{|c|}{$\begin{array}{ll}\text { EDT No. } & 613323 \\
\text { ECN No. } & \text { NA }\end{array}$}} \\
\hline & & & & & \\
\hline \multicolumn{2}{|l|}{ Name } & $\begin{array}{c}\text { Text } \\
\text { With All } \\
\text { Attach. }\end{array}$ & Text Only & $\begin{array}{l}\text { Attach./ } \\
\text { Appendix } \\
\text { Only }\end{array}$ & $\begin{array}{l}\text { EDT/ECN } \\
\text { Only }\end{array}$ \\
\hline $\begin{array}{l}\text { J. G. Field } \\
\text { J. R. Green } \\
\text { C. R. Hoover } \\
\text { E. F. Koeling } \\
\text { W. J. Schlauder } \\
\text { R. J. Smith } \\
\text { G. L. Swearingen } \\
\text { D. W. McNally } \\
\text { K. S. Webster } \\
\text { WHC-SD-TP-PDC-032 File } \\
\text { Central Files }\end{array}$ & $\begin{array}{l}G 1-11 \\
G 1-11 \\
G 1-11 \\
G 3-06 \\
S 7-84 \\
G 1-11 \\
K 8-37 \\
G 1-11 \\
P 7-75 \\
G 1-11 \\
A 3-88\end{array}$ & $\begin{array}{l}x \\
x \\
x \\
x \\
x \\
x \\
x \\
x \\
x \\
x \\
x\end{array}$ & & & \\
\hline
\end{tabular}

